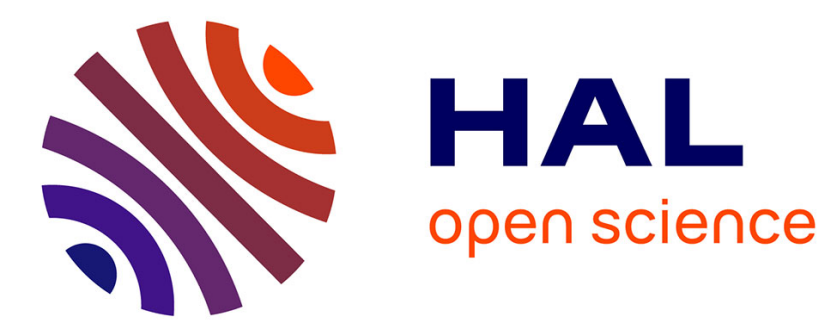

\title{
Water uptake by two contrasting root systems (maize, peach tree): results from a model of hydraulic architecture
}

\author{
Claude Doussan, Gilles Vercambre, Loïc Pagès
}

\section{To cite this version:}

Claude Doussan, Gilles Vercambre, Loïc Pagès. Water uptake by two contrasting root systems (maize, peach tree): results from a model of hydraulic architecture. Agronomie, 1999, 19 (3-4), pp.255-263. hal-00885928

\section{HAL Id: hal-00885928 \\ https://hal.science/hal-00885928}

Submitted on 1 Jan 1999

HAL is a multi-disciplinary open access archive for the deposit and dissemination of scientific research documents, whether they are published or not. The documents may come from teaching and research institutions in France or abroad, or from public or private research centers.
L'archive ouverte pluridisciplinaire HAL, est destinée au dépôt et à la diffusion de documents scientifiques de niveau recherche, publiés ou non, émanant des établissements d'enseignement et de recherche français ou étrangers, des laboratoires publics ou privés. 
(C) Inra/Elsevier, Paris

Original article

\title{
Water uptake by two contrasting root systems (maize, peach tree): results from a model of hydraulic architecture
}

\author{
Claude Doussan $^{\mathrm{a} *}$; Gilles Vercambre ${ }^{\mathrm{b}}$, Loïc Pagès ${ }^{\mathrm{b}}$ \\ a Unité de science du sol, Inra, domaine Saint-Paul, site Agroparc, 84914 Avignon cedex 9, France

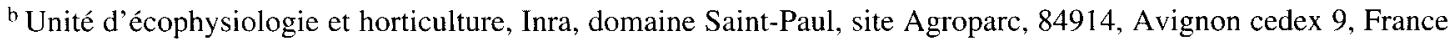

(Received 6 September 1998; accepted 26 January 1999)

\begin{abstract}
This article aims at showing how consideration of architectural and hydraulic features of root systems can help in the understanding of water uptake by plants. Relevant data on architecture and hydraulics of roots can be brought together in the 'Hydraulic Tree Model' of the root system, a model that couples a root system architecture model and laws for water flow to and into roots. In this way, a detailed portrait of water absorption is given, from the single root to the whole root system. Two contrasting plants, maize and peach tree, illustrate model applications and results. These plants not only differ in architectural features, but also in the distribution of hydraulic conductance in the root system. Maize uptake pattern is highly heterogeneous, showing patches of high absorption rates distributed throughout the root system. In contrast, the peach tree is characterized by a localized uptake in the upper, proximal part of the root system. (C Inra/Elsevier, Paris.)
\end{abstract}

water uptake / root / architecture / hydraulic conductance / model

Résumé - Étude de l'absorption hydrique par deux types de système racinaires contrastés avec un modèle d'architecture hydraulique. Le but de cet article est de montrer comment la prise en considération des caractéristiques architecturales et hydrauliques des systèmes racinaires peut aider dans la connaissance du processus d'absorption hydrique. Ces données peuvent être intégrées dans le «Modèle d'Arbre Hydraulique» du système racinaire, qui couple un modèle d'architecture du système racinaire avec les lois de transfert hydrique vers/dans les racines. On obtient ainsi un portrait détaillé du fonctionnement hydrique de l'échelle de la racine à celle du système racinaire complet. L'utilisation du modèle, et ses résultats, sont présentés pour deux plantes très différentes: le maïs et le pêcher. Celles-ci différent non seulement par leurs caractéristiques architecturales, mais aussi par la distribution des conductances hydrauliques dans le système racinaire. Le prélèvement par le maïs est très hétérogène, avec des zones de forte absorption distribuées sur tout le

Communicated by Gérard Guyot (Avignon, France)

* Correspondence and reprints

doussan@avignon.inra.fr 
système racinaire. Le pêcher, au contraire, montre une absorption localisée dans la partie proximale du système racinaire. (@ Inra/Elsevier, Paris.)

absorption hydrique / racine / architecture / conductance hydraulique / modèle

\section{Introduction}

Water uptake in soil by plant roots is often described by considering that the root system is a globally distributed entity in the soil (reflected by the root length density). The calculation of the uptake then consists in defining a 'macroscopic' root sink term (based on the root length density, soil parameters and sometimes a homogeneous root resistance to water flow $[8,10])$, which is incorporated in the Darcy-Richards equation for flow in unsaturated soil. However, these sink functions are largely empirical [17] and need to be fitted to each particular agro-pedo-climatic context. This 'macroscopic' approach puts the emphasis on the soil and the plant is poorly taken into account. For instance, this approach does not consider: i) the geometry of the root system, whereas spatial arrangement of roots in the soil greatly influences water uptake $[24,27]$; ii) the variable absorption capacities of roots; iii) the water transfer in the root system; and iv) the growth of the root system.

Taking into account the architecture of the root system is an explicit and 'natural' way to define more precisely the plant factors influencing the water uptake, by including laws for water transfer into and along the roots. In this way, water uptake is distributed according to the geometry of the root system, and the interaction/competition between different roots is accounted for by the geometry, the connectivity and the hydraulic continuity of roots in the root system. Variations of the root uptake capacity can be considered as a function of age, position or type of the root. Finally, growth is explicitly taken into account.

Such an explicit formulation is now possible because, on the one hand, there are new and detailed data on the local functioning of roots [ 1 , $16,18,25,28]$ and the dynamics of the root system (growth, mortality, branching) [12, 21]; and on the other hand, computer models simulating growth and architecture of root system are now available $[15,20]$, allowing virtual experiments on their interactions with the environment [3].

In this article, we will briefly show how laws for water flow into and along the roots can be coupled with the root system architecture to obtain a 'hydraulic tree model' of the root system. More details about the model can be found in Doussan et al. [5]. Applications of the model are presented for two very different plants - maize and peach tree illustrating two contrasting patterns of hydraulic functioning, and two different uses of the model: reconstruction of the distribution of hydraulic conductances in the root system, or evaluation of water fluxes in the root system for a given set of plant and environmental conditions.

\section{Model development}

Details on the model are given elsewhere [5] and only basic principles are summarized here. The model consists of two main components: a root system architecture model $[20,30]$ and a water uptake model coupling water fluxes and architecture (figure 1). The development of the tridimensional root system is simulated by a set of nodes or segments generated on a 1-day time-step basis. At each time step basic processes are applied to extend the root system: i) emergence of new root axes, ii) growth of the axes, iii) branching, iv) decay and death of axes. These rules depend on the species studied (for example maize emits nodal roots while peach tree does not, peach tree presents evidence of reiteration of main axes (cf. below) which does not appear in maize, etc). Water transfers into and along the simulated root system are represented by a set of connected hydraulic resistances (figure l) simulating hydraulic axial con- 


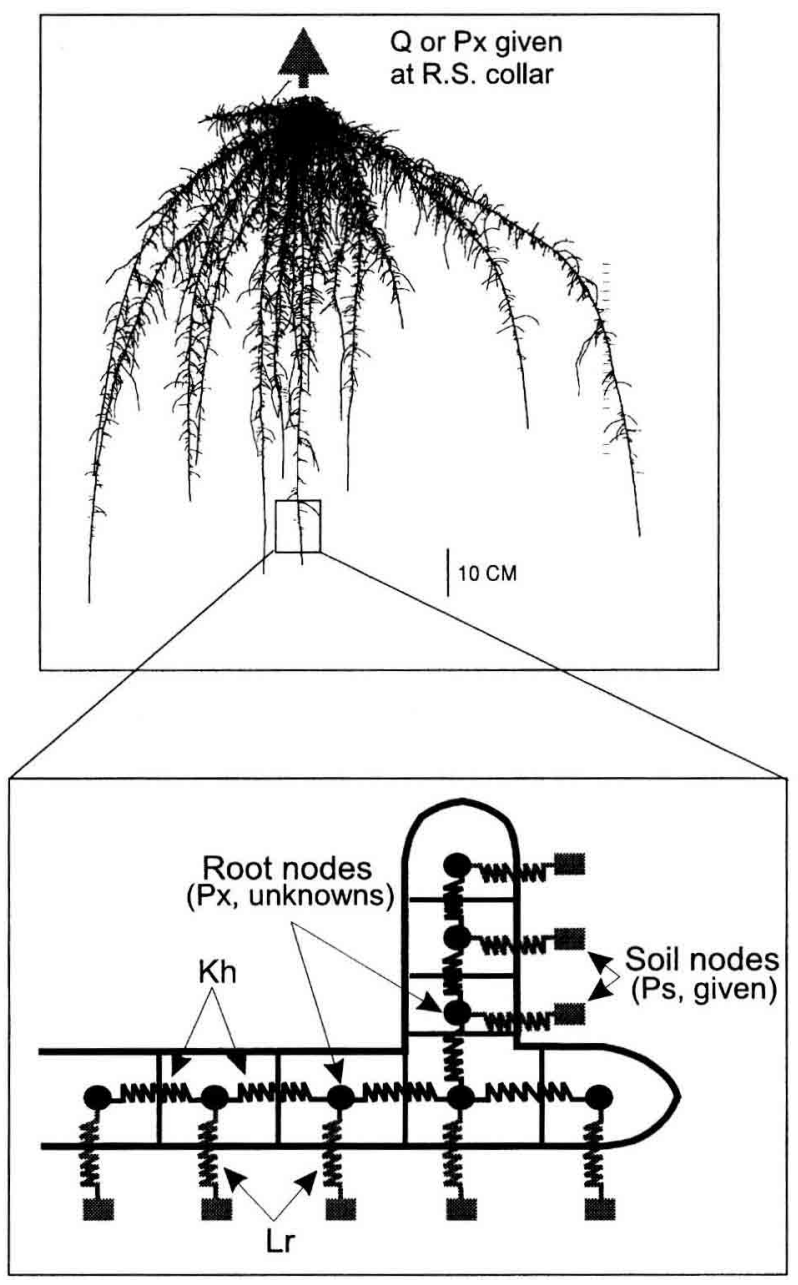

Figure 1. Basic principles of the hydraulic tree model of the root system: a simulated root system is divided into a number of nodes exchanging water through a set of resistances. Water is transported from the soil to the root through a radial hydraulic conductance (Lr) and in the root through axial conductances $(\mathrm{Kh})$. The water potential of the xylem at the root nodes (Px) is unknown and water potential in soil (Ps) is a given boundary condition. A flux or water potential at the basal end of the root system is also needed as a boundary condition.

ductances and radial conductivities [13] distributed within the root system. Axial (Jh) and radial (Jr) fluxes for a root segment are given by:

$$
\begin{aligned}
& J h(z)=-K h \frac{d \psi_{x}}{d z} \\
& J r(z)=-\operatorname{Lr}\left\{\psi_{s}(z)-\psi_{s}(z)\right\}
\end{aligned}
$$

where $\mathrm{Kh}$ and $\mathrm{Lr}$ are the axial conductance and the radial conductivity of the root segment, respectively; $\psi_{\mathrm{x}}(\mathrm{z})$ and $\psi_{\mathrm{s}}(\mathrm{z})$ are the water potentials of the $x y l e m$ and of the soil at distance $z$ from the root apex.

The combination of these flux rate laws with the mass balance applied to the discretized root system gives the fluxes to/into roots ( $\mathrm{Jr}$ and $\mathrm{Jh}$ ) and xylem water potential in the whole root system for a given set of plant boundary conditions. These boundary conditions are: i) the distribution of soil water potential and ii) the water potential of the xylem or the total outflux (transpiration) at the basal end of the root system. The basic assumptions in the model are that the effect of solutes on absorption and the capacitive effect of the roots are negligible.

\section{Illustrating results}

\subsection{A monocotyledon species: maize}

This first case exemplifies the use of the model for deducing the distribution of hydraulic conductances (Kh and Lr) and, consequently, the distribution of water fluxes, in the whole root system. The methodology and details of model inversion can be found in Doussan et al. [6] and only the main results are presented here.

When using the hydraulic tree model of the root system with the experimental data for maize of Frensch and Steudle [9] for $\operatorname{Lr}\left(2.210^{-7} \mathrm{~m} \mathrm{~s}^{-1} \mathrm{MPa}^{-1}\right)$ and $\mathrm{Kh}\left(510^{-11} \mathrm{~m}^{4} \mathrm{~s}^{-1} \mathrm{MPa}^{-1}\right)$, the results showed that: i) only the upper, basal, part of the root system is active in water uptake; ii) along main axes, absorption decreases monotonously from the base to the apex; iii) branches behave as main axes. However, these model results are in contrast with Varney and Canny [28] experimental data for the distribution of water fluxes in main axes and branch roots of maize. These authors observed that water flux was maximum in the distal zone of the axis for main axes and at $40 \mathrm{~cm}$ from the main axis tip for branches. Comparison between simulated and experimental data demonstrates that axial con- 
ductance is limiting for water flow in the simulation and the need to consider heterogeneous distribution of conductances in the root system. This distribution of hydraulic conductances can be found by an inversion process of the model [6], i.e. finding the variations of conductance along roots which give the best fit of water fluxes from the model with the experimental data of Varney and Canny [28]. The result of the inversion process (i.e. variation of axial conductance and radial conductivity of main axes and branch roots of maize) is shown figure 2. An inverse trend between axial conductance and radial conductivity was found, in
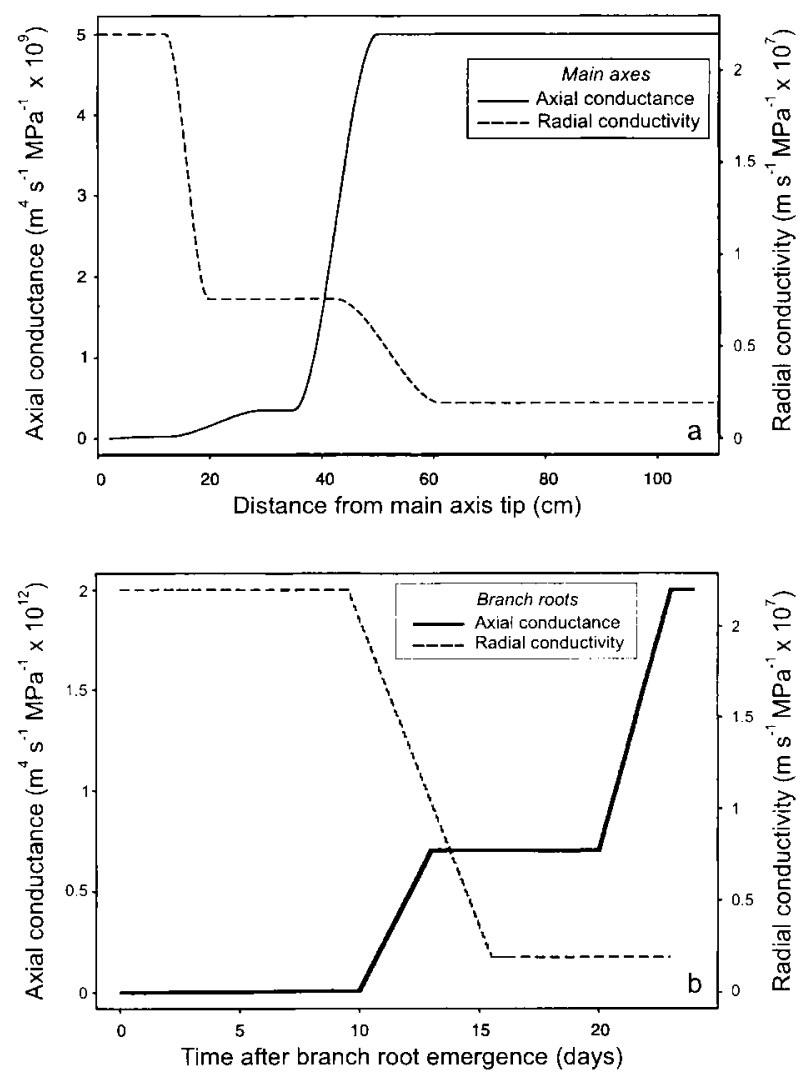

Figure 2. Variation of radial conductivity and axial conductance in maize main axes (a) or branch roots (b) derived from the fitting of the hydraulic tree model of the root system to flux data of Varney and Canny [28]. Redrawn from Doussan et al. [6]. accordance with root anatomical features and ontogeny $[14,22]$. Radial conductivity shows a ten-fold decrease while axial conductance of main axes shows an increase of about four orders of magnitude towards the base of the root. The sudden increase of axial conductance at $40 \mathrm{~cm}$ from the tip for main axes can be related to the delayed development of late metaxylem [16]. In the case of branch roots, the age of the root segment is the pertinent descriptor of conductance variation [6]. Figure 3 shows the water fluxes and water potentials in a maize root system calculated with the conductance variation shown in figure 2 . Water potential of the medium is $0 \mathrm{MPa}$ and the transpiration (total outflux) is $510^{-3} \mathrm{~cm}^{3} \mathrm{~s}^{-1}$. Transpiration induces a tension which propagates throughout the root system. However, young lateral roots and main axes tips show a great attenuation of the tension generated at the root system collar, denoting a very strong axial resistance to water flow. In these parts of the root system, xylem is not mature. High xylem water potential gradients are present in the distal zone of axes and in branch roots, which are related to the slow maturation of late metaxylem. Except the young parts $(2-3 \mathrm{~cm}$ for main axes), almost all of the root system contributes to water absorption. However, absorption appears to be heterogeneously distributed in the root system, even if the external conditions are uniform (the external water potential is $0 \mathrm{MPa}$ ). This behaviour is related to the temporal and spatial variation of root hydraulic conductance. The zones of high water uptake have both a high radial conductivity and an increasing axial conductance. It is worth noting that this root conductance variation leads to a distinct pattern of uptake at each place in the soil where a main axis arrives. Initially, the uptake is low because axe and branch root xylem is not mature, it then increases to a maximum with xylem maturation, and finally decreases with the decline of radial conductivity. Thus, locally, the uptake could decline with time. But at the root system level, as maize continuously develops nodal roots [21], the soil profile will be repeatedly exploited by high uptake capacity roots which will sustain the whole plant water uptake. 

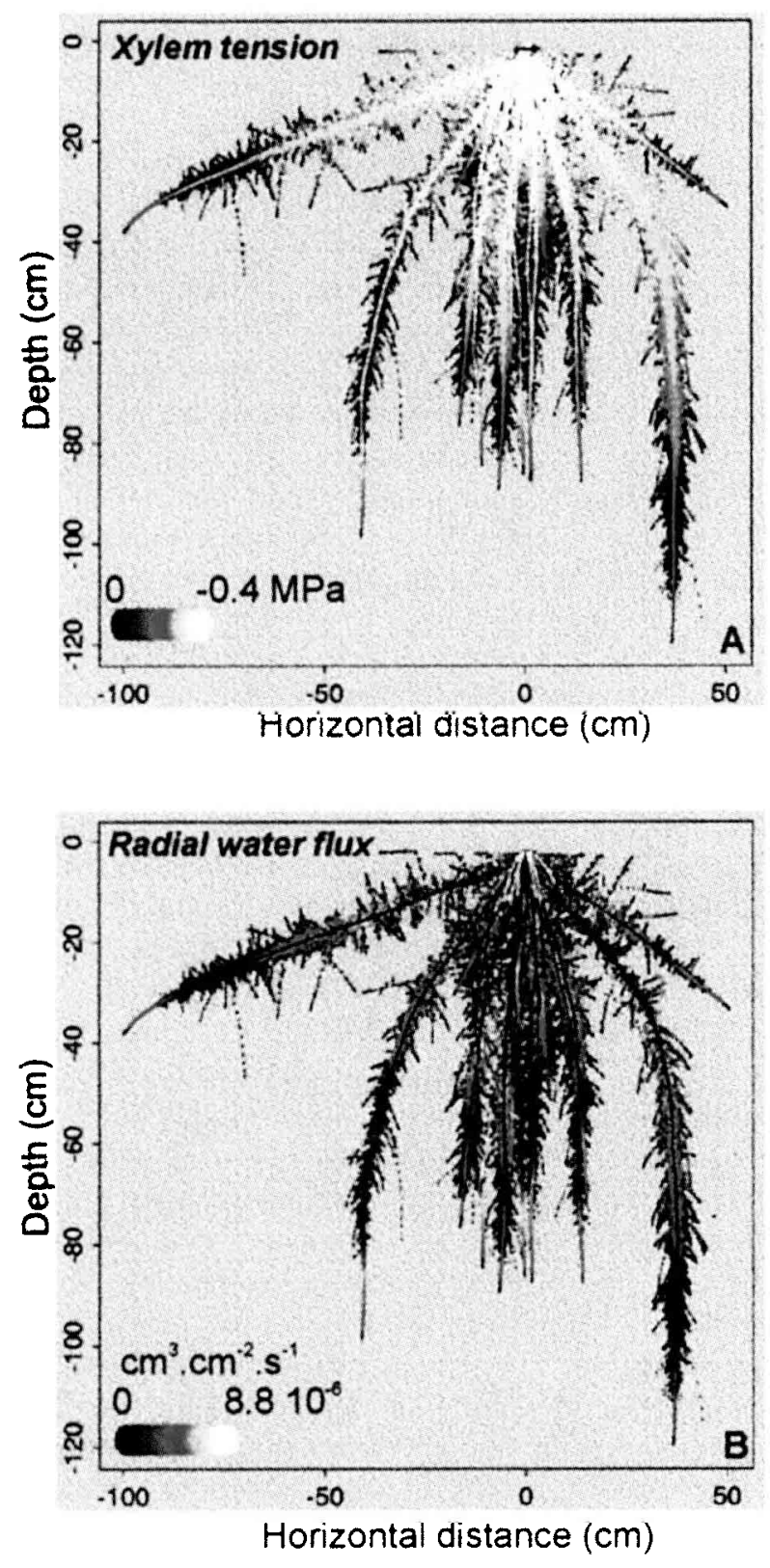

Figure 3. Distribution of the water potential (a) and the water uptake (b) calculated with the hydraulic tree model of the root system for a 43-day-old root system of maize (three-dimensional simulated root system, projected on a vertical plane). The hydraulic conductances of the root system are shown in figure 2. The imposed transpiration is $510^{-3} \mathrm{~cm}^{3} \mathrm{~s}^{-1}$ and the external water potential is fixed to $0 \mathrm{MPa}$.

\subsection{A dicotyledon species: the peach tree}

This second case exemplifies the use of the model in computing the distribution of water uptake in the root system of the peach tree, by taking into account the different features of the peach root system architecture and the measured $\mathrm{Kh}$ and Lr.

The peach root system architecture shows large differences compared to that of the maize root system. Differences are in the number of morphological root types and additional developmental processes. For example, the maize root system presents only two morphological types of root, axile (both seminal and nodal) and lateral (or branch) root, whereas up to six morphological root types are observed for peach [29]. These different types are distinguished according to their axial and radial growth, occurrence of decay, their appearance (woody or not), and their apical diameter. In comparison to maize, where three fundamental developmental processes occur (development of new axes, elongation of axes, branching), three additional processes are important to consider in the peach tree root system: decay and death of roots, reiteration and radial growth [30]. Because of root decay, more than $2 / 3$ of roots disappear along main axes during a 3 -year growth time period, leading to a decrease in branching density in the proximal part of the axes. The large woody roots are the permanent structure of the root system, whereas the fine roots show a high rate of mortality [2]. The other particularity of the peach root system, reiteration, is different from branching. In the latter, the branch roots show large differences in morphological and growth characteristics compared to the mother root. On the contrary, roots issued from reiteration are similar to their mother root and are only main, woody, roots. The origin of reiteration is often related to an injury of a main root tip. The reiteration process allows for a multiplication of the perennial structure of the root system and a denser web of the explored soil volume. Finally, resulting from the cyclic activity of cambium, some roots show an important radial growth. Radial growth is of great importance for anchorage [4] and also, as described below, for the develop- 
ment of the water transfer capacity in the root system.

As with the maize case, peach root axial conductance evolves according to development and maturation of xylem vessels. However, whereas axial conductance of maize roots is only associated with the development of primary structures, parts of the peach root system show secondary radial growth of diffuse-porous wood [7]. Secondary growth is accompanied by a large increase in axial conductance. For a 3-year-old root system, axial conductance of peach roots range from $10^{-14}$ to $510^{-7} \mathrm{~m}^{4} \mathrm{~s}^{-1} \mathrm{MPa}^{-1}$, while maize maximum axial conductance (figure 3) is about $510^{-9} \mathrm{~m}^{4} \mathrm{~s}^{-1} \mathrm{MPa}^{-1}$ [29]. Figure 4 shows the relations between the measured axial conductance and the diameter of fine and woody roots. These relations are quite different, according to the possibility of secondary growth of the root; the increase in root diameter leading to a large increase in axial conductance for woody roots.

Less is known about variations in radial conductivity along root axes, especially for tree root sys-

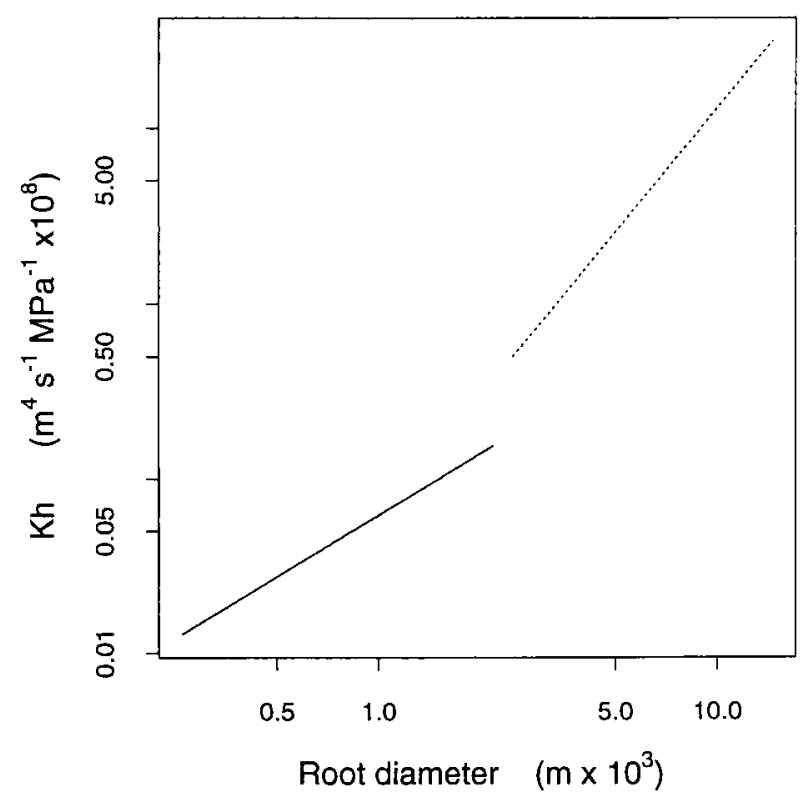

Figure 4. Variation of measured axial conductance of peach roots versus root diameter, for woody (dotted line) and fine root (solid line) types (logarithmic scale). tems, and there are still many controversies concerning the contribution of the older part of the tree root system to water uptake [23]. The measurements we have made on the older part of roots, where suberization and lignification have already occurred give a radial conductivity of about $4.410^{-8} \pm 510^{-9} \mathrm{~m} \mathrm{~s}^{-1} \mathrm{MPa}^{-1}$ for old woody roots and $210^{-9} \pm 6.510^{-9} \mathrm{~m} \mathrm{~s}^{-1} \mathrm{MPa}^{-1}$ for old fine roots [29]. To complement these data, Huang and Nobel [10] describe the variation of radial conductivity (max. $4.210^{-7} \mathrm{~m} \mathrm{~s}^{-1} \mathrm{MPa}^{-1}$ ) along young roots, showing a decreasing trend towards the proximal end. In the peach tree, suberization and lignification occur along an important proportion of the root surface (about $30 \%$ ), and induce a ten-fold decrease of radial conductivity compared to the older part of maize roots.

By incorporating the measured data on peach tree architecture and hydraulic conductances in the hydraulic tree model of the root system, one can obtain a detailed description of the water uptake of the peach tree. As an example (figure 5), this is performed here for a 1-year-old simulated peach root system. The boundary conditions are an imposed water potential both at the root system collar $(-0.8 \mathrm{MPa})$, and in the external medium (soil at saturation: $0 \mathrm{MPa}$ ). Results are shown in figure $5 a$ for water potential and in figure $5 b$ for the radial water fluxes in the root system. Xylem tension increases along the roots with distance from the root base (figure $5 a$ ). The water potential near the root tips is nearly identical to the soil water potential. The xylem water potential gradients in the lateral roots are much less pronounced than in main roots, in contrast to maize (figure $3 a$ ). The calculated total outflow from the root system is $510^{-2} \mathrm{~cm}^{3} \mathrm{~s}^{-1}$, and the radial flux density into roots ranges from 0 to $3.210^{-5} \mathrm{~cm} \mathrm{~s}^{-1}$ (figure $5 b$ ). Clearly from figure 5 , when soil conditions are uniform and not limiting, only a part of the root system is active in water uptake for the peach tree. This is in contrast with maize behaviour (figure 3). In the peach tree, branch roots located in the proximal part of the root system contribute largely to the total uptake. The greater flux densities are essentially located just behind the root tip, where axial conductance is increasing and radial conductivity 

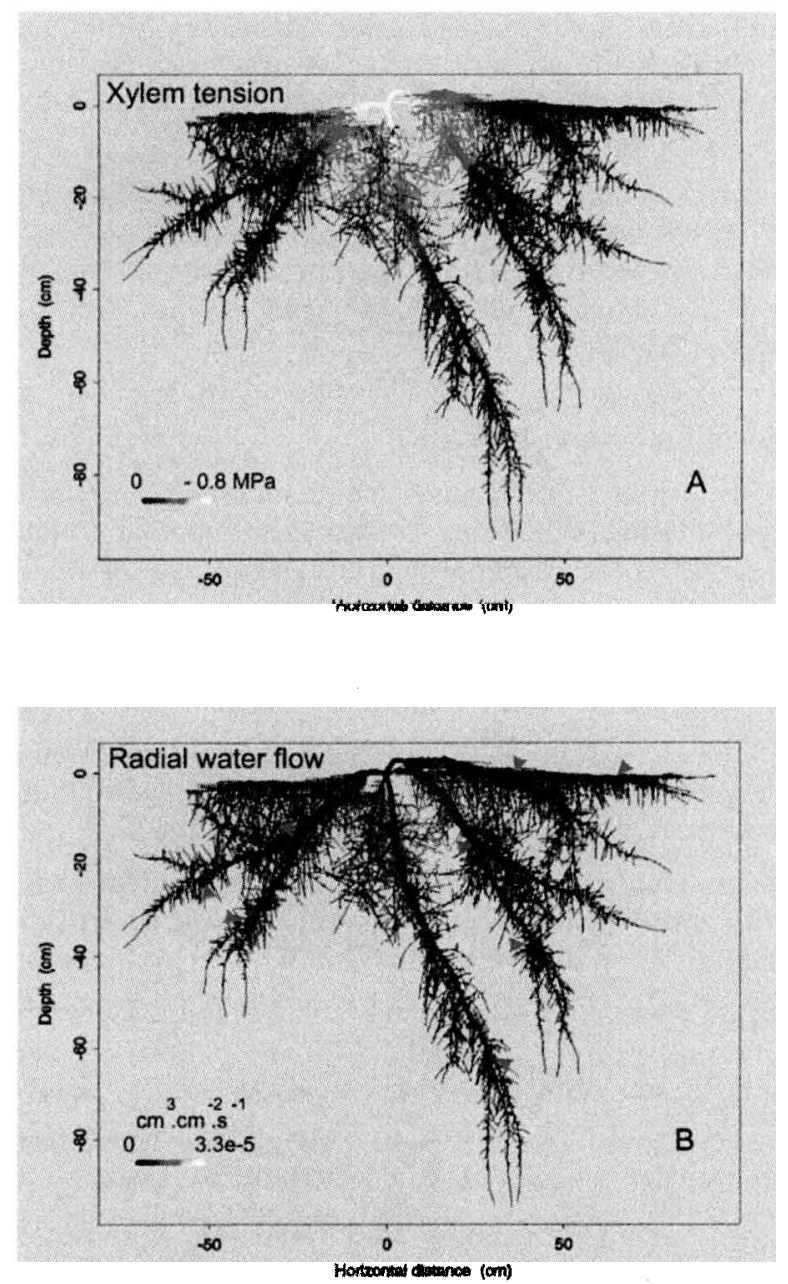

Figure 5. Example of distributions of water potential (a) and water uptake (b) calculated with the hydraulic tree model of the root system for a three-dimensional simulated peach root system (1 year old), projected on a vertical plane. Soil water potential is $0 \mathrm{MPa}$ and the imposed water potential at the basal end of the root system is $-0.8 \mathrm{MPa}$. The red arrowheads show the zones where reiteration occurred.

is not already at its minimum. Furthermore, even if axial conductance is high in main roots, because of the secondary growth, the intensity of water uptake by branch roots leads to a large variation in the water tension in the supporting main roots. In this case, it seems that axial conductance of main axes is too low to transfer adequately the absorbed water, and/or at the root system level, absorption capacity is largely over-sized in comparison with transfer capacity. In fact, numerous authors have shown that wetting a part of the root system can be sufficient to maintain a high transpiration rate [26], pointing out that only a part of the root system may be sufficient for water uptake. Reiterations induce a large multiplication of main roots. For the peach tree the main roots act as parallel sinks for water uptake, increasing the number of roots in the proximal part of the root system, where water potential gradients are maximal.

\section{Conclusion}

Because of the complexity of the root system, plant root characteristics are often over-looked in the plant-soil water relations. A new way to deal with this complexity is to take explicit account of the architecture of the root system. By coupling a root system architecture model [20] and laws which determine flow of water in roots, it was possible to develop a 'Hydraulic Tree Model' of the root system [5]. Such a model gives a quantitative framework, from the single root to the root system level, for examining water uptake as a function of environmental conditions and plant growth. The use of the model is illustrated here by applications on two contrasting plants: maize and peach tree. For maize, we used the model for deducing the distribution of hydraulic conductances in the root system and, consequently the distribution of water fluxes in the whole root system. In this way, we can obtain an estimate of root axial conductance and radial conductivity, particularly in older parts of roots or in branch roots, where experimental data are lacking. The distribution of conductances induces a rather uniform distribution of water potential in the root system, while the distribution of flux is highly heterogeneous, showing patches of high uptake rates.

For the peach tree study, architecture and hydraulic conductance data were gathered from field and laboratory studies $[11,29]$ and inserted in the model to calculate the pattern of water uptake by the peach root system. Peach root system uptake is completely different from maize. It is 
characterized by a localized uptake, in the upper, proximal, part of the root system. Water potential gradually decreases from the main axe tip to the root base, in contrast with maize where water potential appears more uniform.

In these two examples, maize and peach tree, the differences induced in water uptake by the two different architectures and conductance distributions, for the same environmental conditions, can be evaluated by the model. This would have not been the case if the individual data available on architecture or root hydraulics had not been integrated together in this conceptual framework. Finally, even if in the examples shown the soil is not limiting for the uptake, the uptake pattern of the two species studied gives some basis for a better understanding of the uptake in a 'true' soil: i) together with the heterogeneity of soil conditions, the plant related heterogeneity of water uptake induced by the root system architecture and its hydraulics should be considered; ii) we obtain an estimate of the water flux intensity at the root, which is a crucial parameter for water transfer from the bulk soil to the root surface [19]. In the simulated cases the maximum fluxes are about $2-7 \quad 10^{-6} \mathrm{~cm} \mathrm{~s}^{-1}$ for maize, and $1-310^{-5} \mathrm{~cm} \mathrm{~s}^{-1}$ for the peach tree. Such an influence of water fluxes on soil water transfer should be studied by further coupling the 'Hydraulic Tree Model' with water transfers in soil and canopy.

\section{References}

[1] Balling A., Zimmerman U., Büchner K.H., Lange O.L., Direct measurement of negative pressure in artificial-biological systems, Naturwissenschaften 75 (1988) 409-411.

[2] Bloomfield J., Vogt K., Wargo P.M., Tree root turnover and senescence, in: Waisel Y., Eshel A., Kafkafi U. (Eds.), Plant Roots, The Hidden Half, 1996, pp. 659-678.

[3] Clausnitzer V., Hopmans J.W., Simultaneous modelling of transient three dimensional root growth and soil water flow, Plant Soil 164 (1994) 299-314.

[4] Coutts M.P., Developmental processes in tree root systems, Can. J. For. Res. 17 (1987) 761-767.
[5] Doussan C., Pagès L., Vercambre G., Modelling of the hydraulic architecture of root systems: an integrated approach to water absorption - Model description, Ann. Bot. 81 (1998) 213-223.

[6] Doussan C., Vercambre G., Pagès L., Modelling of the hydraulic architecture of root systems: an integrated approach to water absorption - Distribution of axial and radial conductances in maize, Ann. Bot. 81 (1998) 225-232.

[7] Esau K., Anatomy of Seed Plants, 2nd ed., J. Wiley, New York, 1989.

[8] Feddes R.A., Modelling and simulation in hydrologic systems related to agricultural development: State of the art, Agric. Water Manag. 13 (1988) 235-248.

[9] Frensch J., Steudle E., Axial and radial hydraulic resistance to roots of maize (Zea mays L.), Plant Physiol. 91 (1989) 719-726.

[10] Herkelrath W.N., Miller E.E., Gardner W.R., Water uptake by plants: 1. Divided root experiments, Soil Sci. Soc. Am. J. 41 (1977) 1033-1038.

[11] Huang B., Nobel P.S., Root hydraulic conductivity and its components with emphasis on desert succulents, Agron. J. 86 (1994) 767-774.

[12] Jourdan C., Modélisation de l'architecture et du développement du système racinaire du palmier à huile, $\mathrm{Ph} . \mathrm{D}$. thesis, Montpellier II university, 1995.

[13] Landsberg J.J., Fowkes N.D., Water movement through plant roots, Ann. Bot. 42 (1978) 493-508.

[14] Lüttge E., Kluge M., Bauer G., Botanique, TecDoc, Paris, 1992.

[15] Lynch J., Nielsen K.L., Simulation of root system architecture, in Waisel Y., Eshel A., Kafkafi U. (Eds.), Plant Roots: The Hidden Half, Marcel Dekker, Basel, 1996, pp. 247-257.

[16] McCully M.E., How do real roots work?, Plant Physiol. 109 (1995) 1-6.

[17] Molz F.J., Models of water transport in soilplant system: a review, Water Ressour. Res. 17 (1981) $1245-1260$.

[18] North G.B., Nobel P.S., Hydraulic conductivity of concentric root tissues of Agave deserti Engelm. under wet and drying conditions, New Phytol. 130 (1995) 47-57.

[19] Nye P.H., Tinker P.B., Solute movement in the soil-root system, Stud. Ecol. 4 (1977) 12-32.

[20] Pagès L., Jordan M.O., Picard D., A.simulation model of the three-dimensional architecture of the maize root system, Plant Soil 119 (1989) 147-154. 
[21] Pellerin S., Pagès L., Evaluation of parameters describing the root system architecture of field grown maize (Zea mais L.). I. Elongation of of seminal and nodal roots and extension of their branched zone, Plant Soil 164 (1994) 155-167.

[22] Sanderson J., Water uptake by different regions of the barley root. Pathways of radial flow in relation to development of the endodermis, J. Exp. Bot. 34 (1983) 240-253.

[23] Sands R., Fiscus E.L., Reid C.P.P., Hydraulic properties of pine and bean roots with varying degrees of suberification, vascular differentiation and mycorrhizal infection, Aust. J. Plant Physiol. 9 (1982) $559-569$.

[24] Smucker A.J.M., Aiken R.M., Dynamic root response to water deficit, Soil Sci. 154 (1992) 281-289.

[25] Steudle E., Peterson C.A., How does water get through roots?, J. Exp. Bot. 49 (1998) 775-788.

[26] Tan C.S., Buttery B.R., The effect of the soil moisture stress to various fractions of the root system on transpiration, photosynthesis, and internal water rela- tions of peach seedlings, J. Am. Soc. Hort. Sci. 107 (5) (1982) 845-849.

[27] Tardieu F., Bruckler L., Lafolie F., Root clumping may affect the root water potential and the resistance to soil-root water transport, Plant Soil 140 (1992) 291-301.

[28] Varney G.T., Canny M.J., Rates of water uptake into the mature root system of maize plants, New Phytol. 123 (1993) 775-786.

[29] Vercambre G., Modélisation de l'extraction de l'eau par une architecture racinaire en condition de disponibilite hydrique non uniforme, $\mathrm{Ph}$.D. thesis, Institut national agronomique Paris-Grignon, France, 1998.

[30] Vercambre G., Pagès L., Architecture racinaire du pêcher en conditions de verger - Utilisation d'un modèle pour lier des observations statiques et simuler une dynamique de mise en place, in: Architecture et modélisation en arboriculture fruitière, $11^{\mathrm{e}}$ colloque sur les recherches fruitières, Inra-CTIFL, Montpellier, March 1998, pp. 286-292. 